\title{
Introducing the Information Literacy Model "Empowering 8" in South Asia with special reference to India and Sri Lanka
}

\author{
Pradeepa WIJETUNGE \\ Director, National Institute of Library \& Information Sciences, University of Colombo (Sri \\ Lanka) \\ Dr. Jagtar SINGH \\ Head, Department of Library \& Information Science, Punjabi University, Patiala (India)
}

\begin{abstract}
Information literacy (IL) is the ability to identify, locate, evaluate, organize and effectively create, use and communicate information to address an issue or a problem. It is a basic human right to lifelong learning. Information itself is becoming a transforming strategic resource of the emerging information society. Without information literacy, the information society will not be able to achieve its full potential. Therefore, the concept and practice of information literacy must be promoted from an early age among the school going children. Information literacy is more relevant for the developing nations to enable themselves to bridge the growing info-divide between the developed and the developing nations. In this context, a regional workshop was held at the University of Colombo to create awareness of information skills for learning among the participants from South and Southeast Asian countries.
\end{abstract}

Empowering 8 (E8), an Information Literacy Model was developed at this workshop organized jointly by IFLA-ALP and the National Institute of Library \& Information Sciences (NILIS) of Sri Lanka. There were participants representing ten South and Southeast Asian countries. The objective of the workshop was to enhance the resource-based learning in these countries by sensitizing the participants to Information Literacy, which as a concept has not taken roots in majority of the countries in the region. Resource persons from Australia, Canada and Malaysia with ample experience in IL activities facilitated the development of the E8 model.

Introduction of E8 is considered immediately by India and Sri Lanka due to the conducive environment available to the authors from these countries. Through their training programmes and activities, these two authors are planning to sensitize the authorities and the powers that be for the implementation of the E8 model. Later on efforts will be made to implement this model in other countries of the region.

\section{Introduction}




\section{School education system}

India is a union of 28 states, 6 union territories and a national capital territory having a rich composite culture spanning many centuries. Since 1976 state and central governments are responsible for education. Constitution of India provides for three lists; State list, union list and concurrent list.

Under the state lists, state governments are exclusively responsible for education in their respective states. Union government is responsible for maintaining national and integrative character of education under the union list. But both state and central government share responsibility for education in case of partnership under the concurrent list. In the year 2002 the parliament passed the constitution's $86^{\text {th }}$ Amendment Act to make elementary education a fundamental right for children in the age group 6-14 years.

In India school education is imparted at three levels; elementary level (standard 1-8), secondary level (standard 9-10) and higher secondary level (standard 11-12). There are different types of schools in India and this classification can be broadly done on the basis of administering bodies, i.e. Government (state and central), quasi government (army schools), Model schools (Jawahar Navodaya Vidyalayas (JNVs)), public and private schools. Under different boards which develop their curricula and conduct examinations at state and central levels.e.g. CBSE, ICSE and state education boards.

According to Pratham Survey, 25\% of the school children cannot write a dictated sentence even at the age of 14 in the districts in a few states of India. Illiteracy is one of the root causes for poverty and unemployment. The people who are worried about their basic needs of food, clothing and shelter cannot imagine remotely using schools or public libraries. Commercialisation of education has now added a new dimension to the existing problems of school education. (Singh 2004)

There are five types of schools in Sri Lanka at present; Government Schools (9790), Private Schools (68), special schools (17), Pirivenas (Buddhist Monasteries 659) and International Schools (87). Government schools, which offer free education to all including free textbooks and uniform material, are controlled (Funding, Policy Making, Monitoring, Education, Supervision) by the government. These Government schools can be further divided in to two sub categories; National Schools, which are directly controlled by the Ministry of Education (MOE) and Provincial Schools controlled by the eight Provincial Ministries of Education, but under the authority of policy making and monitoring of the MOE.

Development of education has been a key concern of the all-successive governments since independence. Yet there has been a sharp decline in the standards and quality of education at all levels. Several major issues concerning the education system have been identified;

A mismatch between skills provided by the education system and labour market requirements exists. Quality of education is reduced due to the deficiencies in curricula, type of teaching methods, etc. Quality of teaching strength is reduced particularly due to lack of proper training and ad hoc recruitment of teachers irrespective of basic requirements. There are widespread regional disparities in educational facilities. In rural areas educational 
infrastructure is of poor quality. There is a shortage of teaching personnel in rural areas, particularly for science, mathematics and English. Difficulties exist in access to quality primary and secondary education exerting more pressure on urban popular schools. Resource allocation to the education sector is inadequate. Resources available to improve supportive facilities required to raise the quality of education, are insufficient due to the high wage bill in the overall expenditure on education. (Central Bank of Sri Lanka 1998)

\section{Status of School Libraries}

School libraries in both countries face a multitude of problems ranging from inadequate space for keeping books and reading space in school buildings to less trained staff. Nonavailability of regular funds for acquiring reading materials is a major problem faced by school libraries in government and semi-government sector. These schools have only amalgamated funds and parent-teacher association fund from which only a limited number of approved books can be purchased. Schools in the private sector do not have much of a problem with funds but availability to library is subject to priority given to it by the Head of the school. The collections have not grown beyond the prescribed books in the syllabus with a few exceptions. Even the books approved by state directorates of education neither are of good quality nor directly relevant. The ad-hoc system of school libraries is running throughout the length and breadth of the countries in the absence of any specific guidelines and standards for their sustained growth. Rural schools are lagging behind the urban ones in terms of professionally trained library staff. There are no incentives for trained staff for working in rural schools, besides the problems mentioned earlier is manifested to a greater degree. While there is a need for training of professional librarians, mechanisms have not been developed and avenues are not available for this.

Besides, school libraries are facing problems on account of lack of skill, will and awareness; political instability and absence of national policy on library and information system; language diversity and apathetic attitude of authorities.

\section{Education policy reforms}

To overcome the defects of the education system of Sri Lanka, National Education Reforms were formulated. National Education Commission (NEC) identified a set of Overall National Goals and also prepared a list of Educationally Relevant Goals, which are derivatives of these overall national goals with the intention of improving the quality of education. NEC also identified a set of basic competencies, which are essential for the attainment of educationally relevant goals. These basic competencies are;

- Competencies in communication

- Literacy

- Numeracy

- Graphics 
- Competencies relating to the environment

- Social environment

- Biological environment

- Physical environment

- Competencies relating to ethics and religion

- Competencies in play and use of leisure

- Competencies in learning to learn (NEC 1995)

"An action oriented strategy towards a national education policy" (NEC 1995) presented the following five significant policy areas, which fall within the general education, which covers the school education system from primary to senior secondary level;

- Extending educational opportunities

- Improving the quality of education

- Developing practical and technical skills

- Education and training of teachers

- Management of resource provision.

A presidential task force was appointed to implement the policy recommendations in 1996, and 1997 was declared as the "Year of Education Reforms". While the "Action oriented strategy towards a national education policy" dealt with the general education of the country, similar documents were prepared for higher education and technical and vocational education by two other groups of experts and similar task forces were appointed for the implementation of the recommendations.

\section{World Bank projects in support of policy Implementations}

In order to implement the policy recommendations government of Sri Lanka sort aid from foreign missions and the World Bank provided credit for two major projects; General Education Project (GEP) first and second phases and the Teacher Education and Teacher Deployment (TETD) Project.

Second phase of the GEP (GEP2) started in 1997 and expected to be completed in October 2005. Total project value is US\$ million 70. The objectives of the GEP2 are to improve the quality, access, management and financing of existing education programs, and to increase education's responsiveness to economic needs and reducing poverty. There are nine components of this project;

- Curriculum development

- Improving Textbooks/educational publications

- School facilities rationalization

- Quality inputs

- Libraries component

- Education management and planning

- Education financing 
- Impact analysis studies

- $\quad$ Project coordination (World Bank 1997)

\section{Libraries component of GEP2}

According to a survey carried out by the Ministry of Education (MOE) in 1995, out of 8179 schools (excluding schools in North-East Province), $70 \%$ did not have school libraries. Several other significant issues also were identified by the survey and these were discussed in Wijetunge (2002). Following table indicates the library facilities available at different kinds of schools at the time of survey.

Table 1 - Library Facilities available in schools

\begin{tabular}{|l|c|c|c|c|c|}
\hline \multicolumn{1}{|c|}{ Category } & $\begin{array}{c}\text { No. of } \\
\text { Schools }\end{array}$ & $\begin{array}{c}\text { No. of Schools } \\
\text { having permanent } \\
\text { libraries* }\end{array}$ & \% & $\begin{array}{c}\text { No. of Schools having } \\
\text { non -permanent } \\
\text { libraries** }\end{array}$ & \% \\
\hline $\begin{array}{l}\text { Government } \\
\text { schools }\end{array}$ & 9790 & 4000 & 41 & 2000 & 20 \\
\hline Private schools & 85 & 68 & 80 & 17 & 20 \\
\hline $\begin{array}{l}\text { International } \\
\text { schools }\end{array}$ & 87 & 87 & 100 & - & - \\
\hline Pirivenas & 600 & 600 & 100 & - & - \\
\hline
\end{tabular}

*Permanent libraries - A separate place with adequate space according to the standard criteria of the Ministry of Education.

**Non-permanent libraries - A room with some book cupboards, bookshelves or a small collection of books.

Under the Libraries Component of GEP2, School Library Development Unit (SLDU) was established to take leadership in school library development activities. Table 2 depicts the type of infrastructure development activities carried out in 4000 school libraries under the libraries component of GEP2.

Table 2 - Library development activities supported by the Libraries Component 


\begin{tabular}{|c|l|r|l|}
\hline Type of Library & \multicolumn{1}{|c|}{ Definition } & Number & \multicolumn{1}{c|}{ Support received } \\
\hline A & $\begin{array}{l}\text { Senior schools with } \\
\text { grades 10-13 }\end{array}$ & 250 & $\begin{array}{l}\text { Library building, books, } \\
\text { furniture, training and AV } \\
\text { equipment. } \\
25 \text { schools of this category } \\
\text { received Internet facility as } \\
\text { well. }\end{array}$ \\
\hline B & $\begin{array}{l}\text { Junior schools with } \\
\text { classes from grades 1-9 }\end{array}$ & 1750 & $\begin{array}{l}\text { Library building (either new } \\
\text { or renovated), books, } \\
\text { training and furniture }\end{array}$ \\
\hline C & $\begin{array}{l}\text { Middle and small school } \\
\text { in rural and urban areas }\end{array}$ & 2000 & Books and training \\
\hline
\end{tabular}

Since there was a severe lack of trained library professionals, it was decided to develop 4000 teachers as teacher librarians at the beginning and the project was searching for an organisation to undertake this responsibility. A proposal was submitted by the University Grants Commission, to the World Bank to establish a national institute and the World Bank accepted this proposal. NILIS was established in 1999 by an ordinance under section 18 and 24 of the Universities Act No. 16 of 1978 as an institution affiliated to the University of Colombo. Activities of NILIS in educating and training teacher librarians can be found in Wijetunge (2002), Wijetunge (2003) and Wijetunge (2004).

\section{Requirement of the Information Literacy workshop}

The World Bank project in Sri Lanka has supported the infrastructure development of 4000 school libraries (about 50\% of the schools in the country). This initiative was taken to support the resources-based; student centred learning emphasized in the new education policy reforms of Sri Lanka. Even if the physical structures are developed, human resources are not yet developed in all these libraries. Still the library is perceived as a storehouse of books.

In order to promote resource-based student centred learning and to promote competencies in learning to learn, NILIS has incorporated information literacy in all its teacher librarianship programmes. Initially there were no lecturers available with competency to teach this subject but under GEP2 support extended to NILIS Dr. Penny Moore who is an authority on Information Literacy was invited in 2003 to conduct a two-week workshop for NILIS staff. With this initial training NILIS started training teacher librarians in information literacy. However, it was felt that NILIS staff needs more exposure to information literacy.

With the support and guidance of Prof. Russell Bowden who is a member of the Board of Management of NILIS and an Honorary IFLA Fellow, a proposal was developed and submitted to IFLA/ALP to seek funds to conduct a one-week international workshop on Information Skills for Learning. National Institute of Library and Information Sciences is the national body responsible for Library and Information Education of Sri Lanka and also the national institute responsible for the education and training of Teacher Librarians for the 4000 school libraries developed under the World Bank project (and also for other school 
libraries). Therefore it was felt that it is the best institution to undertake this kind of an international workshop and initiate the changing process of 'school libraries' into 'school learning resource centers'.

By conducting this workshop we expected to promote the new $21^{\text {st }}$ century role of the school librarian/teacher librarian, which emphasizes the inculcation of information literacy skills among school children.

Objectives of the workshop were to;

- Re-orient classroom situations from 'chalk and talk' to project-directed learning away from classrooms and into learning information centres;

- To re-position the 'library' as the central core providing students' learning experiences and for teachers as the central resource to guide the learners [away from the age-old 'teaching notes'];

- To re-orient School Libraries from 'libraries' to 'Learning Resource Centres' in order to improve the quality of school education;

- To re-focus school librarianship skills away from materials-based collections' management to active information provision exploiting IT;

- To make known IFLA/UNESCO School Library Manifesto and IFLA / UNESCO School Library Guidelines.

- To define 'information literacy skills' - i.e. 'what is information literacy'? 'What does information literacy look like'? 'What makes it work'? What skills do children require to become information literate?

- To develop strategies in educational institutions for incorporating information literacy skills teaching as an integral part of curricula;

- To develop a realistic model to introduce information skills at national level.

When a plethora of Information Literacy models are already available, one may question why the wheel was being re-invented. Re-inventing the wheel or developing another model was essential because of the composite culture and local conditions in these countries. If an existing model used in a developed country is imposed, it would have been difficult for the stakeholders to understand the philosophical roots behind the model. Therefore, the workshop participants, throughout five days worked from identifying the need of IL through comparison of different models to building the E8 to suit the local needs of the region.

Thirty participants from Bangladesh, India, Indonesia, Malaysia, Maldives, Nepal, Pakistan Singapore, Sri Lanka and Thailand participated at the workshop. Resource persons were from IFLA (Prof. Russell Bowden), IASL (Diljit Singh (Malaysia) and Gerald Brown (Canada)) and ASLA (Karen Bonanno (Australia)), and from Sri Lanka, (Linda Oldham (Sri Lanka)).

The plan of the workshop was as follows;

- Resource persons to introduce the concepts of Resource-based learning, Information skills and the role of $21^{\text {st }}$ century school library.

- Participants to present country status reports, which will be analysed and synthesised along several common themes. 
- $\quad$ One or more lead papers to be presented each day. The participants will engage in group work and plenary sessions along the themes introduced in lead papers.

- A study tour to an international school will be made to gain first hand experience of information skills practice.

- On the fourth day the participants will develop a national model of introducing and integrating information skills into the school curriculum

- On the final day, this national model will be discussed in terms of problems and prospects of implementation.

\section{Empowering 8 Model}

International participants and Sri Lankan participants worked independently to develop an information literacy model and at the end these two models were discussed by both groups with the assistance of the resource persons. Finally both models were refined and merged to form a generic model. This was names as "Empowering 8”. Following table depicts the eight components and the learning outcomes of each component of the model.

Table 3: Components and Learning outcomes of Empowering 8

\begin{tabular}{|c|c|c|}
\hline Step & $\begin{array}{c}\text { Empowering } \\
8 \\
\text { Components }\end{array}$ & The student will be able to demonstrate an ability to: \\
\hline 1 & Identify & $\begin{array}{l}\text { - } \text { Define the topic/subject } \\
\text { - } \text { Determine and understand the audience } \\
\text { - } \text { Choose the relevant format for the finished product } \\
\text { - } \text { Identify the key words } \\
\text { - } \quad \text { Identify different types of resources where information may be } \\
\text { found }\end{array}$ \\
\hline 2 & Explore & $\begin{array}{ll}\text { - } & \text { Locate resources appropriate to the chosen topic } \\
\text { - } & \text { Find information appropriate to the chosen topic } \\
\text { - } & \text { Do interviews, field trips or other outside research }\end{array}$ \\
\hline 3 & Select & $\begin{array}{l}\text { - } \quad \text { Choose relevant information } \\
\text { - Determine which sources are too easy, too hard, or just right } \\
\text { - Record relevant information through note making or making a } \\
\text { - } \text { visual organizer such as a chart, graph, or outline, etc } \\
\text { - } \quad \text { Collect appropriate citations }\end{array}$ \\
\hline 4 & Organise & $\begin{array}{l}\text { - } \quad \text { Sort the information } \\
\text { - } \quad \text { Distinguish between fact, opinion, and fiction } \\
\text { - } \quad \text { Check for bias in the sources } \\
\text { - } \quad \text { Sequence the information in a logical order }\end{array}$ \\
\hline 5 & Create & $\begin{array}{l}\text { - Prepare information in their own words in a meaningful way } \\
\text { - Revise and edit, alone or with a peer }\end{array}$ \\
\hline
\end{tabular}




\begin{tabular}{|c|c|c|}
\hline & & - $\quad$ Finalize the bibliographic format \\
\hline 6 & Present & 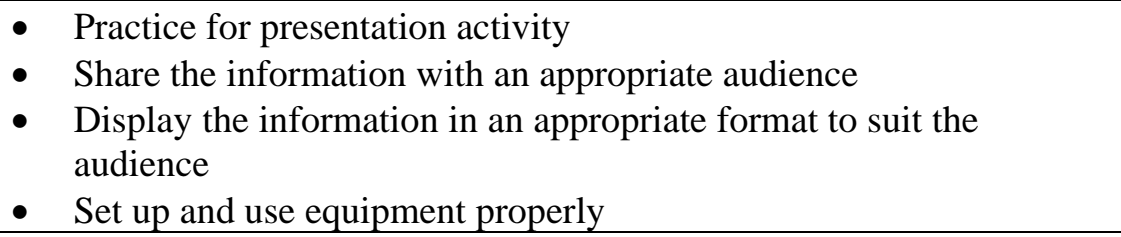 \\
\hline 7 & Assess & $\begin{array}{l}\text { - } \text { Accept feedback from other students } \\
\text { - Self assess one's performance in response to the teacher's } \\
\text { assessment of the work } \\
\text { - } \quad \text { Reflect on how well they have done } \\
\text { - } \quad \text { Determine if new skills were learned } \\
\text { - Consider what could be done better next time }\end{array}$ \\
\hline 8 & Apply & $\begin{array}{l}\text { - Review the feedback and assessment provided } \\
\text { - Use the feedback and assessment for the next learning activity / task } \\
\text { - Endeavour to use the knowledge gained in a variety of new } \\
\text { - } \text { situations } \\
\text { - } \quad \text { Adermine in what other subjects these skills can now be used } \\
\text { - Add product to a portfolio of productions }\end{array}$ \\
\hline
\end{tabular}

\section{Implementation of the model}

\section{E 8: National implementation Committee}

Those who participated at the workshop from all key institutions of Sri Lanka gathered on $23^{\text {rd }}$ December 2004 to discuss the implementation activities of E8 on different platforms. It was unanimously decided to formulate a national implementation committee. Members unanimously agreed that the positions of Chairperson and Secretary should be with NILIS since NILIS was responsible for organizing the Workshop. Members also agreed that Prof. Bowden should chair the committee and Mrs. Wijetunge to be the Secretary. They both accepted the posts.

Members also decided that the National Implementation Committee (E8 NIC) should have a focus group with a limited number of members from the key institutions, which will be the stakeholders for implementing the model; NILIS, School Library Development Unit, UGC, National Library, Sri Lanka Library Association, National Inst. of Education, and the commissioner of National Colleges of Education.

It was decided that these focus group members should represent the interests of their respective institutes and that they should report the E8 NIC decisions to their institution and vice versa. This focus group will meet as and when necessary to take key decisions regarding promotion and implementation.

It was decided to invite the following to become members of the main 'Empowering 8 National Implementation Committee'. This will meet to endorse the interim work of the 
Focus Group and to provide advice on general policies and strategies relevant at the national level.

- 8 Provincial Education Directors

- 8 Provincial Library Co-ordinators

- Representative from Faculty of Education, University of Colombo

- Representative from Faculty of Education, University of Jaffna

- Representative from Dept. of Education, University of Peradeniya

- Representative from Dept. of LIS, University of Kelaniya

- Representative from Sri Lanka Teacher Librarians Association

- A principal from Type $1 \mathrm{AB}$ School

- A Principal from Type 1C school

- A Principal from Type 2 school

- A principal from Type 3 school

- 17 representatives from 17 NCOEs

- Any other person / persons considered as significant for the promotion and implementation of 'Empowering 8'.

E8 NIC Focus Group members are encouraged to establish Sub-Focus Groups within the respective institutions to facilitate communications and inter-actions.

\section{Copyright of 'Empowering 8'}

NILIS took action to obtain copyright of "Empowering 8" to NILIS to assure that the right of use of the concept and its products will be legally controlled by NILIS. Any organization wishing to use 'Empowering 8' for workshops, or any similar events, will be required to obtain the written permission of the Director/NILIS. NILIS would take legal action against any organizations or individuals, which violate the copyright of 'Empowering 8'.

A reputed advertising company was commissioned to design a logo for the model in order to register it as a trademark in order to provide additional protection against mis-use.

\section{Future activities}

The following activities were discussed and planned:

\section{Launch of the Proceedings}

A Launch of the Proceedings and the Logo was held on $19^{\text {th }}$ May, with the participation of the Secretary to the MOE, so that the key stakeholders from the MOE will be informed of the model. 


\section{Follow-up workshop for participants of the first workshop}

Committee agreed that a follow up workshop of 5-days is most desirable in order to be able to complete the Empowering 8 model in order to develop the model further to a an implementable level.

\section{National Conference on Empowering 8}

It was decided that on completion of the 'follow up' Workshop a National 'Empowering 8' Conference should be held in Sri Lanka, for principals and other educators to promote the take-up and use in Sri Lanka of Empowering 8 within the curriculum.

\section{Translation of the model into Sinhala and Tamil}

Asst. Librarian of NILIS who participated at the workshop has already translated the model into Sinhala, and a participant from the National Library was assigned the translation into Tamil. Once completed the translations will be evaluated by the focus group members for accuracy and before being adopted. Together with the model, IFLA/UNESCO School Library Manifesto also was translated into Sinhala.

\section{Implementation of the workshop resolutions}

Following are some of the significant resolutions proposed, seconded and voted at the workshop;

o That the International Federation of Library Associations (IFLA) Section on School Libraries and Resource Centres to continue the excellent work of the "School Library Manifesto" by developing an "Information Literacy Policy” statement.

o That the International Association of School Librarianship (IASL) be requested to produce a policy statement on Information Literacy that can be circulated both in print and electronically to the South and South East Asia region.

o That the Library Association and / or School Library Association in each of the workshop participant countries be urged to develop an information literacy policy statement, and to promote it to education government authorities within their jurisdiction.

o That information literacy skills for learning should be integrated in primary and secondary schools and in teacher education curriculum in South and South East Asian schools to bring awareness in use of school libraries.

o IFLA and IASL cooperate in the preparation of a glossary of terms related to Information Literacy Policy development, and that this information be available on the website of both associations, and also as a print publication on demand. 
o That IFLA Standing Committee for Asia and Oceania endorse the establishment of an electronic discussion list of representatives to the "Information Skills for Learning Workshop”, based at NILIS Sri Lanka, and that a small start-up grant of \$ US 5,000 be requested.

o That the "Empowering Eight" Model be widely promoted by "Information Skills for Learning Workshop” participants at different platforms in South and South East Asian countries to develop information literacy programs and skills.

o That Library Associations and School Library Associations be urged to provide continuing professional development and education opportunities in relation to their Information Literacy Policy statement, and to report actions to IFLA and IASL by 01 May 2005, through NILIS contact officers.

o A committee comprising representatives from Sri Lanka NILIS, NIE, NCOE, NLDSB and the SLDU(MOE), who participated in the "Information Skills for Learning Workshop”, produce a trainers' manual as a guideline to introduce the concept, information literacy, as a way of learning and as a source for learning with an eclectic approach to empower people, ensuring lifelong education.

o 11. That a committee representing the "Information skills for Learning workshop" delegates be formed to prepare a memo for distribution to education authorities on the issue of treating school librarians on a par with school teachers.

\section{Follow-up workshop}

Developing "The Empowering 8 Problem-Solving Model" as a dimension of information literacy provided the beginning stages in the exploration of an idea that can permeate pedagogy at many levels and stages of education. The follow up workshop should be seen as stage 2 of that empowerment for the learners in the workshop. It became apparent as the workshop evolved, that there were many new ideas and new teaching methods that could be explored in greater depth in order to make Empowering 8 a much more effective tool.

Objectives of the proposed follow up workshop are to;

- Review the concepts at each stage of the Empowering 8 Problem-Solving Model as specific steps in the definition of information literacy, as a refresher for continuing participants, and as an up-grade for newcomers to the workshop.

- Investigate the skills needed to make it possible for an independent learner to apply E8 in personal learning settings.

- Identify the aspects of the Components of a Modern Quality School Library Program that match each stage in the $\mathrm{E} 8$ model.

- Clarify and specify the roles of the teacher, teacher-librarian, and administration in the implementation of the $\mathrm{E} 8$ model in an educational setting. 
- Consider the training requirements for a teacher-librarian to be able to implement the specific role identified above.

- Devise rubrics for the assessment and evaluation stage of E 8 that are directly linked to both the content and skills identified in the specific learning outcomes of any assignment.

- Draft a generic Information Literacy Policy statement as related to the UNESCO IFLA School Library Manifesto, and the IFLA / UNESCO School Library Guidelines for use in the participant's local setting.

- Outline specific steps for implementing the above Information Literacy Policy.

- Detail personalized specific steps for implementing E8 as a problem-solving model in the agencies or institutions represented by the individuals in the workshop, and in teams, if more than one representative from a country is in attendance.

\section{Conclusion}

By now it is clear that data are stray facts without any context, and information is meaningful data. The domain of information is decision making. Knowledge deals with problem-solving, and wisdom focuses upon the consequences of our decisions. Information is a critical resource for human progress. Hence there should not be any compromise in promoting the concept and practice of information literacy. The role of IFLA-ALP and IASL is appreciable with regard to creating awareness about information literacy among school children, teacherlibrarians, and school authorities in South and Southeast Asia. This is obvious from the funding provided for the Colombo workshop in November 2004, and further commitment of US\$ 12, 000 for the follow-up workshop at Punjabi University, Patiala (India). Whereas the role of Unesco in this regard deserves a critical an objective review. Nevertheless, the followup workshop is going to take place in September/October 2005, thanks to the magnanimity of the IFLA-ALP. It will be a dawn of information literacy in South and Southeast Asia in general, but in India and Sri Lanka in particular.

\section{References}

Central Bank of Sri Lanka (1998). Economic progress of independent Sri Lanka. Colombo. Central Bank of Sri Lanka.

NEC. National Education Commission. (1995). An action oriented strategy towards a national education policy. Colombo. NEC.

Singh, Jagtar (2004). India: status of school library development. IN: Sri Lanka. Proceedings of the international workshop on Information Skills for Learning. Ed. by Gerald R. Brown, Russell Bowden and Pradeepa Wijetunge. Colombo. NILIS. pp. 51- 55.

World Bank (1997). General Education Project (02). [on line] (URL http://www.worldbank.org.lk). Accessed 10.02.2005. 
Wijetunge, Pradeepa (2002). Empowering students towards a Knowledge Society through a school library development project: a conceptual model for Sri Lanka. IN: School libraries for a knowledge society. Proceedings of the $31^{\text {st }}$ annual conference of the IASL. Ed. by Diljit Singh ... [et.al.]. Washington. IASL. pp. 251 - 264.

Wijetunge, Pradeepa (2003). The survival of National Institute of Library and Information Sciences in a turbulent public university environment. Malaysian Journal of Library and Information Science, 8(2), pp. 109 -130.

Wijetunge, Pradeepa (2004). Education and Training of Teacher Librarians in Sri Lanka. Asian Library News. 6(2), pp. 24 -29.

Pradeepa Wijetunge is presently, Director, National Institute of Library and Information Sciences (NILIS), University of Colombo. (Sri Lanka). A Master of Librarianship (Library Automation) from University College of Wales, Aberystwyth, and a winner of the Leadership Development Award 2005 (IASL), she is a prolific writer and a dynamic leader. She has contributed about 50 publications in the field of library and information science and has 20 years of professional experience. She has organized and attended many professional workshops. In November 2004, she organized the IFLA-NILIS Regional Workshop on Information Skills for Learning in which professionals from South and Southeast Asia participated along with resource persons from Australia, Canada, and Malaysia. She has developed curricula for the courses being offered by the NILIS and is actively involved in the teaching and consultancy work. She is a member of CILIP (UK) and other library associations in Sri Lanka. Currently, she is involved in Teacher Librarian training programme supported by the World Bank at NILIS. She is a widely traveled person, and her areas of interests include LIS Education, Teacher Librarianship, Knowledge Management and Information Literacy.

Dr. Jagtar Singh is presently Reader and Head, Department of Library and Information Science, Punjabi University, Patiala (India). He is a Gold Medalist of Punjab University, Chandigarh, and a widely traveled person. He has 21 years of teaching and research experience. With more than 100 publications, Dr. Singh is life member of all the library associations in India. He has been associated with the OCLC and IFLA Projects also. He was awarded Commonwealth Fellowship for post-doctoral research on electronic publishing at Loughborough University in the UK. A winner of the Ken Haycock Leadership Development Award 2004 (IASL), he is currently involved in a project to extend public library services to rural folks in Punjab with the help of PIOs (NRIs) and government authorities. He is on the editorial board of many professional journals. Diversity of his research interests ranges from rural libraries to multimedia virtual libraries. He is also Vice-President of the Indian Library Association and General Secretary of the Punjab Library Association. 
Reproduced with permission of the copyright owner. Further reproduction prohibited without permission. 